\title{
OMNIBUS LAW TENTANG PENGATURAN TEKNOLOGI INFORMASI DAN KOMUNIKASI GUNA REKONSTRUKSI KONVERGENSI HUKUM TEKNOLOGI
}

\author{
(Omnibus Law Concerning Arrangement of Information and Communication Technology for \\ Reconstruction of Technology Law)
}

\author{
Nurul Ula Ulya \\ Fakultas Hukum Universitas Brawijaya \\ Jalan MT. Haryono No.169 Malang, Jawa Timur \\ e-mail: lialea65@gmail.com \\ Fazal Akmal Musyarri \\ Fakultas Hukum Universitas Brawijaya \\ Jalan MT. Haryono No.169 Malang, Jawa Timur \\ e-mail: fazalakmalmusyarri.bu@gmail.com
}

Naskah diterima: 15 Februari 2020; revisi: 5 April 2020; disetujui: 6 April 2020

\begin{abstract}
ABSTRAK
Perkembangan teknologi merupakan suatu keniscayaan yang mewarnai kehidupan manusia modern saat ini. Untuk menghindari hal-hal yang dapat merugikan masyarakat, peranan hukum menjadi penting dalam mendampingi perkembangan teknologi. Namun hingga saat ini, masih terdapat celah hukum yang menimbulkan permasalahan seperti kasus Hoaks Ratna Sarumpaet, sengketa Nama Domain BMW.id, dan aduan tentang Financial Technology karena hukum yang belum akomodatif. Penelitian ini menggunakan metode Yuridis Normatif dengan pendekatan peraturan perundangundangan serta pendekatan konseptual. Terdapat beberapa topik mayor yang diangkat dalam tulisan ini diantaranya Hoaks, Nama Domain Indonesia, Start-Up, Financial Technology, Keterbukaan Informasi Publik, Pelayanan Perizinan Perusahaan dan Konvergensi dengan Hukum Telematika. Permasalahan pada topik mayor tersebut tersebar dalam peraturan perundang-undangan di berbagai tingkatan, yang akan penulis bahas dalam tulisan ini. Peneliti juga memberikan saran revisi substansi atas topik mayor tersebut yang diwujudkan melalui momentum Omnibus Law tentang Teknologi Informasi dan Komunikasi guna lus Constituendum hukum Indonesia.
\end{abstract}

Kata Kunci : hukum TIK, konvergensi hukum dan teknologi, omnibus law

\begin{abstract}
The development of technoogy has being the way of modern human life today. To avoid many things those can harm the society, legal role becomes very important to be on the side of technology developments. But until right now, there are still legal gap cause problems arise which are about ratna sarumpaet case, BMW.id Domain Name dispute, complaint about Financial Technology Implementation and many more that caused by unaccomodative law. The author used the research method of Juridical Normative using a statute approach and conceptual approach. There are several major topics raised in this paper including Hoax, Indonesian Domain Names, Start-up, Financial Technology and Public Information Openness. Also about corporate licensing services and convergence with legal telematics. The Issues on the major topic are reflected through legislation at various levels, those will be discussed in this paper. The researcher also provides a suggestion for the revision of the substance on the major topic which can be implemented through the momentum of the Omnibus Law. Keywords : IT law, the convergence of law and technology, omnibus law
\end{abstract}




\section{A. Pendahuluan}

Pasal 28C Undang-Undang Dasar Negara Republik Indonesia Tahun 1945 menjadi dasar pondasi yang secara filosofis melandasi perkembangan teknologi di Indonesia. Adapun nomenklatur lengkap dari Pasal 28C ayat (1) UUD NRI 1945 berbunyi :

"Setiap orang berhak mengembangkan diri melalui pemenuhan kebutuhan dasarnya, berhak mendapat pendidikan dan memperoleh manfaat dari ilmu pengetahuan dan teknologi, seni dan budaya, demi meningkatkan kualitas hidupnya dan demi kesejahteraan umat manusia"

Pasal tersebut membuktikan bahwasannya dalam penyelenggaraan dan pengembangan Ilmu Pengetahuan dan Teknologi didukung dan dijamin oleh negara. Sehingga setiap Warga Negara memiliki hak untuk mengoptimalkan potensi yang telah dianugerahkan oleh Tuhan Yang Maha Esa termasuk dalam hal teknologi. ${ }^{1}$ Salah satu bentuk perkembangan dari teknologi adalah sistem informasi.

Sistem Informasi mampu melahirkan bentuk dunia lain selain dunia nyata yaitu yang seringkali disebut sebagai dunia maya sebagai disrupsi sistem konvensional. ${ }^{2}$ Dalam sistem bertransaksi yang pada awalnya hanya menggunakan sarana fisik seperti uang kartal dan giral, saat ini dapat memanfaatkan perangkat nirkabel seperti Kartu Kredit, Kartu
Debit dan Kartu ATM. Bahkan di beberapa dekade akhir, sistem transaksi sudah dapat dilakukan melalui uang elektronik yang tidak terlihat wujudnya. ${ }^{3}$

Teknologi Informasi dan Komunikasi (TIK) juga menciptakan Sistem E-Commerce yang terintegrasi dengan sistem pembayaran elektronik. E-Commerce ialah transaksi bisnis yang dilakukan dengan teknologi media digital serta terjadi perpindahan mata uang pada transaksi tersebut. Adapun dalam transaksi ini menggunakan beberapa sistem pembayaran yang antara lain Kartu Kredit Daring, Dompet Digital, Digital Cash, StoredValue, Digital Accumulating Balance, Cek Digital, dan Pembayaran Nirkabel. ${ }^{4}$

Secara sosiologis, perkembangan TIK mempengaruhi pola kehidupan masyarakat, yang ditandai dengan peningkatan aktivitas E-Commerce. Google dan Temasek menyatakan perputaran uang aktivitas perekonomian secara digital di Indonesia mencapai angka US\$ 27 Miliar pada tahun 2018. ${ }^{5}$ Pertumbuhan yang akseleratif ini menjadikan Indonesia sebagai negara dengan pertumbuhan perekonomian sektor digital yang paling maju di Asia Tenggara. Selain faktor geografis juga dipengaruhi oleh perubahan sosial pola kehidupan masyarakat Indonesia yang menjadikan teknologi informasi dan komunikasi sebagai penopang

Saldi Isra, "Peran Mahkamah Konstitusi dalam Penguatan Hak Asasi Manusia di Indonesia," Jurnal Konstitusi, Vol.11, No.3 (September 2014): 414.

2 Akh. Mardani, Konsekuensi-Konsekuensi Modernitas: Perubahan Perilaku Konsumen dan Kontestasi Tanda di Dunia Maya, Tesis, (Surabaya: Universitas Airlangga, 2017), hlm.23.

3 Direktorat Akunting dan Sistem Pembayaran dan Direktorat Pengedaran Uang Bank Indonesia, Laporan Pembayaran dan Pengedaran Uang, (Jakarta: Penerbit Bank Indonesia, 2008), hlm.9-15.

4 Hestin Mulyasari, Thanh Thi Bi Dan, dan A. Bima Murti Wijaya, "Analisis Jenis Sistem Pembayaran Elektronik dalam Transaksi E-Commerce di Indonesia" (makalah disampaikan pada Seminar Nasional Teknologi Informasi dan Komunikasi (SENTIKA), Yogyakarta, 15 Mei 2014). (ISSN : 2089-9813).

5 Google dan Temasek, e-Conomy SEA 2018 - Southeast Asia's Internet Economy Hits an Inflection Point, (Singapura: Penerbit Google dan Temasek, 2018), hlm.6. 
aktivitas. ${ }^{6}$ Aktivitas E-Commerce yang sering dilakukan oleh pengguna internet meliputi pencarian barang atau jasa melalui internet, mengunjungi toko daring dan pembelian produk melalui gawai. ${ }^{7}$ Akseptasi masyarakat juga mendukung tumbuh kembangnya TIK yang menurut APJII, jumlah pengguna internet di Indonesia hingga tahun 2016 mencapai angka 132,7 juta orang. ${ }^{8}$

Sebagai contoh dari perkembangan TIK ialah Financial Technology yang mampu memberikan efek disruptif yang merusak pasar layanan pengelolaan keuangan konvensional. ${ }^{9}$ Beberapa bentuk Financial Technology misalnya di bidang Payment, Crowdfunding dan P2P Lending. ${ }^{10}$ Selain itu dalam sektor publik terdapat pula amanat dari peraturan perundang-undangan untuk transparansi keterbukaan publik melalui Pejabat Pengelola Informasi dan Dokumentasi (PPID). ${ }^{11}$ Sektor usaha juga tidak luput dengan adanya integrasi perizinan terpadu melalui Open Single Submission (OSS) yang mudah digunakan karena memanfaatkan sistem website. $^{12}$

Pembahasan mengenai fenomena global yang saat ini telah memasuki era digital juga memberikan posisiyangbesarkepadaTeknologi
Informasi dan Komunikasi untuk memberikan pengaruh salah satunya terhadap aspek bisnis dan perusahaan. Momentum Revolusi Industri 4.0 mencetuskan model bisnis baru yang disebut dengan Start-Up, yang merupakan model bisnis dengan karakteristik yang lekat dengan Teknologi Informasi dan Komunikasi sebagai sarana usahanya. Start-Up yang pada umumnya memiliki perbedaan dengan perusahaan konvensional. Dikarenakan Start-Up mengakomodasi peranan Teknologi dalam strategi berwirausaha, maka dalam struktural Start-Up selalu terdapat posisi Chief Technology Organizer (CTO). Karakteristik lainnya adalah Start-Up juga memerlukan pendanaan oleh Angel Investor dan melewati tahapan yang tidak diperlukan oleh perusahaan konvensional. ${ }^{13}$

Masih dalam topik mengenai korelasi antara Teknologi Informasi dan Komunikasi dan aspek ekonomi adalah berkaitan dengan pengaturan Nama Domain khususnya Nama Domain Indonesia yang ternyata dewasa ini memiliki nilai ekonomi dan dapat divaluasi sehingga dapat menjadi komoditi yang berharga. Nama Domain Indonesia dengan ekstensi yang unik merupakan aset perusahaan yang dapat memiliki nilai yang

6 Aldo Fenalosa, "Kilas Balik Ecommerce Platform di Indonesia Tahun 2018," iPrice, https://iprice.co.id/trend/ insights/kilas-balik-e-commerce-di-indonesia-tahun-2018/ (diakses 12 Februari 2020).

7 Wicaksono Febriantoro, "Kajian dan Strategi Pendukung Perkembangan E-Commerce Bagi UMKM di Indonesia," Jurnal Manajerial, Vol.3, No.5 (Juni 2018): 189.

8 Berry A. Harahap, dkk., Perkembangan Financial Technology terkait CBCD terhadap Transmisi Kebijakan Moneter dan Makroekonomi, (Jakarta : Bank Indonesia, 2017), hlm.14.

9 Nofie Iman, "Financial Technology dan Lembaga Keuangan", (makalah disampaikan pada acara Gathering Mitra Linkage BSM, Hotel Grand Aston, Yogyakarta, 22 November 2016).

10 H2 Ventures dan KPMG, 2018 Fintech100 - Leading Global Fintech Innovators, (Sydney: Penerbit H2 Ventures dan KPMG, 2018), hlm.4.

11 Daniar Supriyadi, Hukum dan Sistem Informasi Legislasi, (Malang: Penerbit Nuswantara, 2017), hlm.61.

12 Kementerian Koordinator Bidang Perekonomian Republik Indonesia, Pedoman Perizinan Berusaha Melalui Sistem OSS untuk Pelaku Usaha, (Jakarta: Kementerian Koordinator Bidang Perekonomian Republik Indonesia, 2018), hlm.3.

13 Doni Wijayanto, Legal Start-Up Business, (Solo: Penerbit Metagraf, 2018), hlm.59. 
tinggi karena tidak hanya merepresentasikan identitas namun juga untuk keperluan bisnis. Nama Domain saat ini telah menjadi kebutuhan khususnya jika ditinjau dari kepemilikan Nama Domain Indonesia yang mencapai angka 344.361 pada 2019. ${ }^{14}$

Selain memberikan warna pada hukum privatsepertipenggunaankontrakelektronik ${ }^{15}$, Teknologi Informasi dan Komunikasi juga menyentuh hukum pidana yang mana arah pengaturannya berfokus pada kejahatan dan pelanggaran yang menggunakan Teknologi Informasi dan Komunikasi. Kejahatan Mayantara (Cyber Crime) dapat berupa pencurian data secara ilegal misalnya kartu kredit hingga penyebaran informasi yang tidak benar atau hoaks dan kejahatan kejahatan tradisional yang memanfaatkan Teknologi Informasi dan Komunikasi. ${ }^{16}$

Ditinjau dari statistika dan permasalahan di lapangan, problematika yang muncul berkaitan dengan beberapa permasalahan diatas juga kerap kali terjadi bahkan telah sampai di ranah litigasi. Dikarenakan dalam beberapa kajian memperlihatkan bahwa rumusan norma dalam Undang-Undang Informasi dan Transaksi Elektronik bersifat multitafsir atau pasal karet sehingga menimbulkan banyak permasalahan hukum. Di sepanjang tahun 2019, terdapat beberapa kasus yang digarisbawahi merupakan akibat dari rumusan yang kurang jelas dalam undangundang tersebut. ${ }^{17}$

Begitu pula dalam konteks hukum keperdataan, terdapat beberapa kasus yang telah dibawah ke meja hijau seperti misalnya dalam aspek Nama Domain Indonesia, terdapat sengketa kasus BMW.id yang terjadi antara Benny Muliawan melawan perusahaan otomotif Bayerische Motoren Werke AG (BMW). Kasus itu merupakan kasus yang telah berlarut-larut terjadi semenjak sekitar tahun 2015 dan masih dibawa ke pengadilan hingga kini. Kasus itu telah melewati beberapa proses penyelesaian seperti pada panel Penyelesaian Perselisihan Nama Domain (PPND) PANDI, Pengadilan Negeri Tangerang, Pengadilan Tinggi Banten, dan sekarang sedang dimohonkan kepada Mahkamah Agung. ${ }^{18} \mathrm{Hal}$ tersebut dikarenakan tidak adanya konstruksi hukum keperdataan yang tepat bagi Nama Domain Indonesia dan nafasnya kurang selaras di dalam materi muatan UndangUndang Informasi dan Transaksi Elektronik.

Financial Technology juga menjadi aspek keperdataan yang dapat menimbulkan permasalahan hukum jika tidak diselesaikan dalam tataran normatif. Lembaga Bantuan Hukum (LBH) mencatat terdapat sekitar 1330 aduan dari masyarakat berkaitan dengan implementasi Financial Technology yang kurang efektif. Aduan itu diterima hanya dalam jangka waktu 2016 hingga 2018. ${ }^{19}$

\footnotetext{
14 PANDI, "Statistik PANDI," PANDI, https://pandi.id/statistik/ (diakses 13 Februari 2020).

15 Shinta Dewi, CyberLaw - Praktik Negara-Negara dalam Mengatur Privasi dalam E-Commerce, (Bandung : Penerbit Widya Padjajaran, 2009), hlm.60.

16 Maskun, Kejahatan Siber - Cybercrime, (Jakarta: Penerbit Kencana, 2013), hlm.33.

17 Haris Prabowo, "Banjir Kasus Pasal Karet UU ITE Sepanjang 2019", Tirto.id, https://tirto.id/banjir-kasus-pasalkaret-uu-ite-sepanjang-2019-eo4V (diakses 04 Maret 2020).

18 Febri Ardani, "Babak Baru Sengketa Domain BMW.id", CNN Indonesia, https://www.cnnindonesia.com/ teknologi/20180818233634-384-323295/babak-baru-sengketa-domain-bmwid (diakses 19 Maret 2020).

19 Puspita Saraswati, "AFPI Dalami Kasus Pelanggaran Standar Penagihan FINTECH", Kontan, https://keuangan. kontan.co.id/news/afpi-dalami-kasus-pelanggaran-standar-penagihan-fintech (diakses 07 Agustus 2019).
} 
Belum lagi permasalahan kontekstual yang berpotensi muncul pada ranah lain seperti perkembangan Start-Up berbasis teknologi dan kebijakan dalam bidang telekomunikasi yang dapat dikatakan mulai usang serta kebijakan keterbukaan informasi publik yang juga belum efektif hingga kini.

\section{Kompleksitas pengaturan tentang} Teknologi Informasi dan Komunikasi menjadi potensi permasalahan kontekstual di masa yang akan datang karena dapat memicu isu hukum seperti antinomi atau konflik hukum dan kekaburan hukum yang menimbulkan kondisi ketidakpastian hukum. Sehingga momentum Omnibus Law menjadi solusi tepat integrasi seluruh hukum yang mengatur tentang Teknologi Informasi dan Komunikasi ke dalam satu peraturan perundang-undangan yang arah pengaturannya bersifat menyeluruh, komprehensif dan holistik. Secara definitif, Omnibus Law berarti hukum untuk semua yang tidak terikat pada satu rezim pengaturan saja namun membuat kondisi berkesinambungan antar peraturan yang saling berkaitan satu sama lain. ${ }^{20}$ Mengingat usia dari rezim hukum siber di Indonesia yang belum terlampau tua sehingga menjadi momentum yang tepat untuk membuat pembaharuan dan rejuvenasi hukum ke arah yang lebih progresif.

Berdasarkan paparan latar belakang, maka rumusan masalah yang diangkat dalam karya ilmiah ini adalah: Pertama, bagaimana analisis normatif problematika pengaturan Teknologi Informasi dan komunikasi di Indonesia pada saat ini? Kedua, bagaimana konsep Omnibus Law dalam kerangka Teknologi Informasi dan Komunikasi untuk lus Constituendum di masa yang akan datang?

\section{B. Metode Penelitian}

Jenis penelitian ini adalah yuridis normatif atau disebut juga penelitian hukum doktrinal ${ }^{21}$, yaitu peneliti menelaah bahan hukum sekunder $^{22}$ kemudian dilanjutkan dengan penelitian terhadap data primer di lapangan untuk menjawab permasalahan yang menjadi fokus penelitian yang mengkonsepkan hukum. Adapun metode pendekatan yang digunakan di dalam penelitian ini adalah menggunakan pendekatan perundang-undangan (StatuteApproach) ${ }^{23}$ dan Konseptual (ConseptualApproach). ${ }^{24}$

\section{Pembahasan}

\section{Problematika Yuridis Pengaturan Hukum Teknologi Informasi dan Komunikasi di Indonesia Saat Ini}

Beberapa peraturan perundang-undangan di Indonesia mengatur tentang aspek Hukum Teknologi Informasi dan Komunikasi, yang saat ini sentralistis berpusat pada UndangUndang Informasi dan Transaksi Elektronik. Fokus materi muatan dalam Undang-Undang Informasi dan Transaksi Elektronik pada umumnya berkelindan pada aspek hukum publik, misalnya diakomodasinya bidang hukum pidana yang merupakan transformasi

\footnotetext{
20 Henry Donald Lbn. Toruan, "Pembentukan Regulasi Badan Usaha dengan Model Omnibus Law", Jurnal Hukum tô-râ, Vol.3, No.1 (April 2017): 465.

21 Sukismo B., Karakter Penelitian Hukum Normatif dan Sosiologis, (Yogyakarta: Penerbit PUSKUMBANGSI LEPPA UGM, tanpa tahun), hlm.8.

22 Roni Hanitijo Soemitro, Metodologi Penelitian Hukum dan Jurimetri, (Jakarta: Penerbit Ghalia, 1988), hlm.10.

23 Peter Mahmud Marzuki, Penelitian Hukum, (Jakarta: Penerbit Kencana, 2007), hlm.96.

24 Johnny Ibrahim, Teori dan Metodologi Penelitian Hukum Normatif, (Malang: Penerbit Bayumedia, 2007), hlm.391.
} 
pengaturan tindak pidana tradisional yang memanfaatkan Teknologi Informasi dan Komunikasi. Konstruksi pengembangan tersebut termaktub pada Pasal 27 hingga Pasal 37 Undang-Undang Informasi dan Transaksi Elektronik. ${ }^{25}$ Implementasi dari yurisdiksi Hukum Pidana Siber tersebut memiliki konsep yang serupa dengan hukum pidana konvensional yang tidak hanya dapat menjerat Warga Negara Indonesia namun juga Warga Negara Asing baik yang berada di dalam maupun di luar wilayah Negara Kesatuan Republik Indonesia yang merugikan Indonesia ataupun dunia. ${ }^{26}$

Namun di sisi lain, Undang-Undang Informasi dan Transaksi Elektronik berusaha mengakomodasi aspek-aspek hukum privat seperti penggunaan atau kegiatan transaksi yang memanfaatkan Teknologi Informasi dan Komunikasi. Perkembangan teknologi memungkinkan transaksi yang menggunakan kontrak elektronik dengan konsep Electronic Data Interchange (EDI) sehingga perbuatan hukum dapat juga dilakukan tanpa harus bertatap muka. Hukum positif mengakui variasi transaksi yang demikian dan bahkan validitasnya dapat digunakan sebagai alat bukti yang sah di hadapan pengadilan. ${ }^{27}$ Begitu juga dengan pengaturan mengenai data pribadi, dimana sebagian aspek data pribadi telah terakomodasi dalam undang-undang ini. Misalnya dalam hal penggunaan dari data pribadi oleh perusahaan penyelenggara layanan teknologi yang mana harus atas persetujuan pengguna layanan. ${ }^{28}$

Masalah yang dapat ditemukan dari pengejawantahan Undang-Undang Informasi dan Transaksi Elektronik adalah maraknya penyebaran berita bohong atau Hoaks yang sulit dikendalikan di masyarakat yang juga sebagai imbas dari peraturan perundangundangan yang kurang tegas dalam mengatur tentang peredaran informasi. Dalam frasa yang dikonstruksikan pada nomenklatur pasal yang mengatur berkaitan dengan Hoaks, penafsiran terhadap klausul-klausul yang ada di dalamnya bersifat rancu sehingga di kalangan penegak hukum sendiri tidak terdapat pemahaman tunggal yang merujuk pada konsepsi penegakan untuk Hoaks yang serupa. ${ }^{29}$ Di dalam Undang-Undang Informasi dan Transaksi Elektronik, konsepsi pengaturan yuridis tentang Hoaks dapat ditemukan pada Pasal 45 A ayat (1) dan Pasal 45 A ayat (2) Undang-Undang Nomor 19 Tahun 2016 tentang Perubahan Atas Undang-Undang Nomor 11 Tahun 2008 tentang Informasi dan Transaksi Elektronik. Dijelaskan bahwasannya setiap orang dilarang menyebarkan informasi yang memiliki muatan berita bohong dan menyesatkan yang dapat menimbulkan rasa kebencian atau permusuhan individu dan/atau kelompok masyarakat tertentu berdasarkan atas SARA. ${ }^{30}$

Maskun, Kejahatan Siber - Cybercrime, (Jakarta: Penerbit Kencana, 2013), hlm.33.

26 Sigid Suseno, Yurisdiksi Tindak Pidana Siber, (Bandung : Penerbit PT Refika Aditama, 2012), hlm.296.

27 Niniek Suparni, Cyberspace dan Antisipasi Pengaturannya, (Jakarta: Penerbit Sinar Grafika, 2009), hlm.65\&127.

28 Sinta Dewi Rosadi, Cyber Law - Aspek Data Privasi Menurut Hukum Internasional, Regional dan Nasional, (Bandung: Penerbit PT Refika Aditama, 2015), hlm.103-104.

29 Adami Chazawi dan Ardi Ferdian, Tindak Pidana Informasi dan Transaksi Elektronik, (Malang : Penerbit Media Nusa Creative, 2015), hlm.132.

30 Husnul Hotimah, Hoax dalam Perspektif Undang-Undang Nomor 19 Tahun 2016 tentang Informasi dan Transaksi Elektronik dan Hukum Islam, Skripsi, (Jakarta: UIN Syarif Hidayatullah Tangerang, 2018), hlm.3. 
Penegakan hukum terhadap permasalahan Hoaks tersebut apabila ditinjau dari segi politik hukum dari Undang-Undang Informasi dan Transaksi Elektronik akan membuka celah permasalahan yuridis dari pemberlakuan konsepsi pengaturan tentang Hoaks yang belum sepenuhnya terintegrasi secara sempurna karena konstruksi hukum yang dibangun lebih kepada distraksi antara tindak pidana yang bersifat konvensional dengan pola digital yang memanfaatkan Teknologi Informasi dan Komunikasi. Disparitas antara konstruksi materi muatan yang dipaksakan dengan penegakan hukum atas Hoaks yang tidak mangkus dan sangkil membuat permasalahan Hoaks menjadi isu hukum yang sulit untuk terpecahkan khususnya dari segi prosedural penegakan hukumnya yang dapat menghambat kondusifitas hukum di Indonesia. ${ }^{31}$

Adapun permasalahan berkaitan dengan Nama Domain adalah jenis perjanjian yang digunakan yaitu perjanjian jual beli. Apabila ditinjau dari Hukum Perdata, perjanjian jual beli adalah suatu perjanjian timbal balik yang mana pihak yang satu berjanji untuk menyerahkan hak milik atas suatu barang, sedangkan pihak yang lain berjanji untuk membayar harga yang terdiri atas sejumlah uang sebagai imbalan dari perolehan hak milik tersebut. ${ }^{32}$ Sehingga unsur mutlak yang setidaknya harus ada dalam perjanjian jualbeli meliputi: 1) adanya perikatan antara pihak penjual dan pembeli; serta 2) objeknya berupa penyerahan hak milik dan pembayaran sejumlah nominal harga yang telah ditentukan atau disepakati. ${ }^{33}$

Sedangkan apabila dikembalikan dalam konsep registrasi Nama Domain baik di tingkat nasional maupun secara global, prosedur pendaftaran Nama Domain tidak sesederhana seperti konsep dalam perjanjian jual-beli. Dalam perjanjian jual-beli, setelah dilakukan penyerahan (Levering) hak milik atas suatu benda yang disertai pembayaran harga, perikatan tersebut selesai atau hapus. ${ }^{34}$ Sedangkan dalam konsep registrasi Nama Domain, Pembayaran atas Nama Domain akan dilakukan oleh Registran setiap jangka waktu tertentu, pada umumnya dilakukan dalam jangka waktu tahunan tergantung pada pilihan yang dipilih Registran saat mendaftarkan Nama Domain. ${ }^{35}$ Registran menerima tagihan (Invoice) yang mewajibkan Registran untuk membayar dalam nominal yang sama seperti pembayaran pertama kali saat registrasi. Bahkan dalam perkembangan beberapa Top Level Domain (TLD), nominal yang harus dibayar dapat naik setiap tahunnya. Bila definisi dari Perjanjian JualBeli tersebut direfleksikan dalam bingkai transaksi pendaftaran Nama Domain, maka

31 Khoiruddin Manahan Siregar, "Integrasi Politik Hukum terhadap Tindak Pidana Pemberitaan Palsu (Hoax) di Indonesia," Fitrah Jurnal Kajian Ilmu-Ilmu Keislaman, Vol.4, No.2 (Desember 2018): 240.

32 R. Subekti, Aneka Perjanjian, (Bandung : Penerbit PT Citra Aditya Bakti, 1989), hlm.1.

33 Djohari Santoso dan Acmad Ali, Hukum Perjanjian Indonesia, (Yogyakarta: Penerbit Perpustakaan Fakultas Hukum Universitas Islam Indonesia, 1989), hlm.115.

34 Salah satu hubungan hukum yang dapat menghapuskan perikatan adalah pembayaran. dalam Hartono Hadisoeprapto, Seri Hukum Perdata : Pokok-Pokok Hukum Perikatan dan Hukum Jaminan, (Yogjakarta: Penerbit Liberti, 1984), hlm.47.

35 PANDI, "Perpanjang Domain," PANDI, https://pandi.id/mengelola-domain/perpanjang-domain/ (diakses 13 Februari 2020). 
secara esensial, perjanjian registrasi Nama Domain tidak cocok apabila dikategorisasikan jenisnya sebagai perjanjian jual-beli. Dan hal tersebut membuat hubungan keperdataan Nama Domain menjadi hal yang rancu untuk dikonkritkan dalam hukum positif.

Adapun problematika dalam lingkup perkembangan Teknologi Informasi dan Komunikasi selanjutnya adalah mengenai hal komplementer yang juga menyokong perkembangan teknologi yaitu eksistensi model bisnis yang disebut dengan Start-Up. Start-Up memiliki ciri yang berbeda dengan perusahaan konvensional, yang dalam konteks ini ialah ketergantungan atas penggunaan Teknologi Informasi dan Komunikasi dalam aktivitas bisnisnya, yang oleh karena itu juga struktur perusahaan Start-Up berbeda karena terdapat organ bernama Chief Technology Organizer (СTO) selain CEO, CME, CFO, COO dan lain sebagainya. Karakteristik lainnya ialah dalam pengembangan teknologi yang digunakan tersebut memerlukan peran Angel Investor untuk menyuntik dana yang sangat besar sehingga Start-Up bisa tumbuh dengan cepat. $^{36}$ Strategi yang digunakan oleh Start-Up dalam bisnisnya sering disebut sebagai "Bakar Uang" yaitu penggelontoran dana demi ekspansi pasar dan valuasi perusahaan yang tinggi ${ }^{37}$ dan berpotensi dapat menguasai pasar dan terdapat kecenderungan praktik monopoli. Konstruksi yang demikian membedakan Start-Up dengan bisnis konvensional yang berorientasi pada profit sedangkan Start-Up lebih pada valuasi perusahaan. Pola itu dalam studi ekonomi dapat mengarahkan pada kondisi Bubble Economic yang bersifat merusak karena berpotensi menimbulkan ledakan keruntuhan perekonomian. ${ }^{38}$

Permasalahannya hingga saat ini belum ada hukum yang secara tegas mengatur tentang Start-Up. Dari sisi hukum perusahaan, Start-Up dengan karakteristik diatas dibebaskan memilih bentuk baik PT, CV, Firma ataupun Maatschap, tidak memberi perlindungan terhadap investor karena karakteristik kepemilikan harta perusahaan. ${ }^{39}$ Selain itu dalam hukum investasi juga dana suntikan Start-Up sulit diawasi oleh BKPM karena belum ada hukum Start-Up sebagai konvergensi hukum dan teknologi. ${ }^{40}$

Adapun permasalahan dalam Financial Technology pada POJK Nomor 77/ POJK.01/2016 tentang Layanan Pinjam Meminjam Uang Berbasis Teknologi Informasi yang belum mengakomodasi

36 Andika Drajat, Dika Kartika, Start-Up Guidebook, Panduan Memulai Start-Up Bisnis Yang Harus Kamu Tau, (Bantul: Penerbit Quadrant, 2017), hlm.57-59.

37 Arif Budiansyah, "Bukalapak Hingga Dana, Ini Start-Up yang Masih Bakar Uang," CNBC Indonesia, https://www. cnbcindonesia.com/tech/20191210151827-37-121924/bukalapak-hingga-dana-ini-Start-Up-yang-masihbakar-uang (diakses 13 Februari 2020).

38 Rabbit Antonio, "Fenomena Bakar Uang Ala Start-up dan Gelembung Ekonomi," Kompasiana, https://www. kompasiana.com/basingbe/5defa080097f36616a7a4d92/fenomena-bakar-uang-ala-startup-dan-gelembungekonomi?page=1 (diakses 13 Februari 2020).

39 Doni Wijayanto, Legal Start-Up Business, (Solo: Penerbit Metagraf, 2018), hlm.59.

40 PP No.44 Tahun 2016 tentang Daftar Bidang Usaha yang Tertutup dan Daftar Bidang Usaha yang terbuka di Bidang Penanaman Modal merupakan mekanisme hukum bagi investor untuk menanamkan, namun belum ada nomenklatur tentang Start-Up baik dari segi persyaratan maupun limitasi investasi hingga teknis kategorisasi terbuka atau tertutupnya bidang usaha. 
kepentingan hukum Financial Technology. ${ }^{41}$ Misalnya mengenai E-Know Your Customer, Resiko Bank Shadow, tumpang tindih percepatan gerilya Financial Technology dan dilematika pencegahan pencucian uang dan pendanaan terorisme. ${ }^{42}$ Dalam POJK Nomor 13/POJK.02/2018 tentang Inovasi Keuangan Digital di Sektor Jasa Keuangan, terdapat masalah kurangnya efektivitas Regulatory Sandbox yang merupakan mekanisme pemantauan dan pengawasan. ${ }^{43}$ Permasalahan terkait perlindungan data pribadi juga menjadi salah satu anotasi dalam Peraturan OJK tersebut yang menjadi masalah dalam praktik Financial Technology. ${ }^{44}$

Di dalam keterbukaan informasi publik, permasalahan terletak pada instansi PPID yang tidak presisi dan satu pintu. Hal tersebut dikarenakan juga belum diterapkannya teknologi yang disebut dengan Web Semantik yang seharusnya dapat membantu otomatisasi pelayanan di bidang keterbukaan informasi publik. Kemudian berkaitan dengan pengurusan izin usaha dimana pemerintah telah menerbitkan Peraturan Pemerintah Nomor 80 Tahun 2019 tentang Perdagangan Melalui Sistem Elektronik (PMSE) yang tidak adanya mekanisme sanksi jika pelaku usaha tidak memenuhinya.

Topik mayoryang terakhirialah konvergensi antara Undang-Undang Telematika dan Undang-Undang Informasi dan Transaksi Elektronik adalah rezim Hukum Siber yang kurang akomodatif atas Teknologi Informasi dan Komunikasi. Misalnya VoIP dan Broadband yang belum terkonvergensi dengan masalah teknologi saat ini. Sehingga jika tidak akan mengurangi efektivitas Teknologi Informasi dan Komunikasi. ${ }^{45}$

Ditinjau dari permasalahan penegakan hukum sebagai bahan hukum yang dapat menunjang problematika yang telah dijelaskan diatas sebetulnya juga berangkat dari isu normatif karena penegakan Hukum Teknologi Informasi dan Komunikasi Indonesia tidak ditopang dengan peraturan perundang-undangan yang memadai. Dalam konteks hukum pidana, permasalahan berita palsu masih menjadi momok jagat dunia maya. Beberapa kasus seperti penyebaran Isu Rush Money oleh Abu Uwais ${ }^{46}$ dan bahkan telah ada kasus yang selesai disidangkan dan berkekuatan hukum tetap seperti kasus

41 Raisa Venalia, "Pengawasan Otoritas Jasa Keuangan terhadap Layanan Pinjam Meminjam Berbasis Teknologi Informasi Dihubungkan dengan Prinsip Transparansi dalam Mekanisme Financial Technology di Indonesia," Prosiding Ilmu Hukum, Vol.5, No.1 (Februari 2019): 167.

42 Nanda Narendra Putra, "Fintech Rawan Dipakai untuk Pencucian Uang dan Pendanaan Terorisme," Hukum Online, http://www.hukumonline.com/berita/baca/lt5946e 0e4c4d4c/fintech-rawan-dipakai-untuk-pencucian-uangdan-pendanaan-terorisme (diakses 13 Februari 2020).

43 M. Syahran W. Lubis, "OJK Terbitkan Aturan Fintech, Ini Poin-Poinnya", Bisnis, https://finansial.bisnis.com/ read/20180902/89/834081/ojk-terbitkan-aturan-fintech-ini-poin-poinnya (diakses 13 Februari 2020).

44 Jonathan Hendson Passagi dan Reski Amalia, "Mengenal Financial Technology di Indonesia," CTRL+ Bulletin, Artikel 1, (2019): 10.

45 Ahmad M. Ramli, "Dinamika Konvergensi Hukum Telematika dalam Sistem Hukum Nasional," Kemenkumham, http://ditjenpp.kemenkumham.go.id/hukum-teknologi/668-dinamika-konvergensi-hukum-telematika-dalamsistem-hukum-nasional.html (diakses 13 Februari 2020).

46 Muhammad Syaidri, "Berkas Lengkap, Penyebar Isu Rush Money Segera Disidang", JawaPos, https://www. jawapos.com/nasional/hukum-kriminal/25/01/2017/berkas-lengkap-penyebar-isu-rush-money-segeradisidang/ (diakses 04 April 2020). 
penyebaran hoaks penganiayaan Ratna Sarumpaet. ${ }^{47}$

Hukum keperdataan juga termasuk dalam kajian ini. Nama Domain Indonesia adalah satu hal yang memerlukan penguatan normatif karena adanya kasus seperti BMW.id yang diperselisihkan oleh Benny Muliawan dan Perusahaan Otomotif BMW. Kasus ini telah berjalan selama lima tahun lamanya dan hingga kini belum mencapai titik terang. Hal ini terjadi karena kurang kuatnya bangunan hukum Nama Domain Indonesia termasuk dalam hal keperdataan seperti hak kebendaan apa yang melekat, apakah hak lisensi ataukah hak milik. ${ }^{48}$ Begitu juga dengan hukum Financial Technology yang marak digunakan oleh masyarakat saat ini. Laporan yang masuk seperti bunga yang sangat tinggi dan tanpa batas (1.145 nasabah), penagihan ilegal dan penyebaran foto (1.100 korban), dan keluhan terkait dengan tindakan ancaman, fitnah, pelecehan seksual, dan penipuan (781 nasabah). ${ }^{49}$ Yang terakhir ialah isu yang menerpa bangunan perusahaan berbasis teknologi seperti StartUp. Kerugian yang dialami Bukalapak menjadi contoh bahwa konstruksi hukum yang labil akan memberikan kerugian seperti kepada investor dan pengguna layanan. ${ }^{50}$

\section{Konsep Omnibus Law tentang Hukum Teknologi Informasi dan Komunikasi sebagai lus Constituendum Konvergensi Hukum Teknologi}

Pembentukan rezim Hukum Siber di Indonesia mengalami sejarah yang cukup panjang sebelum diundangkannya UndangUndang Informasi dan Transaksi Elektronik. Kajian mengenai Hukum Siber telah dilakukan sejak tahun 1999 yang pada awalnya diinisiasi oleh Pusat Studi Cyberlaw Fakultas Hukum Universitas Padjajaran bersama dengan Jurusan Teknologi Elektro Institut Teknologi Bandung dan Direktorat Jenderal Pos dan Telekomunikasi. Berdasarkan kajian dan perdebatan yang panjang, tiga pihak pioner tersebut berhasil melahirkan Naskah Akademik Rancangan UndangUndang Pemanfaatan Teknologi Informasi. Tidak hanya akademisi dari Universitas Padjajaran dan Institut Teknologi Bandung, akademisi hukum dari Fakultas Hukum Universitas Indonesia juga turut mewarnai alur sejarah lahirnya rezim Hukum Siber di Indonesia. Pada tahun 2000, Lembaga Kajian Hukum Teknologi Informasi Fakultas Hukum Universitas Indonesia bersama Departemen Perindustrian dan Perdagangan juga turut menyusun rancangan Hukum Siber berupa Naskah Akademik Rancangan Undang-Undang Informasi Elektronik dan Transaksi Elektronik.

47 Mac Aditiawarman, dkk., Hoax dan Hate Speech di Dunia Maya, (Padang: Penerbit Lembaga Kajian Aset Budaya Indonesia Tonggak Tuo, 2019), hlm.141.

48 Freddy Harris, "Konstruksi Hukum Nama Domain: Sebuah Kepemilikan atau Lisensi", Kemenkumham, http:// ditjenpp.kemenkumham.go.id/hukum-teknologi/669-konstruksi-hukum-nama-domain-sebuah-kepemilikanatau-lisensi.html (diakses 23 Maret 2020).

49 Nindya Aldila, "Aduan Masyarakat : Kasus Fintech Lending Meningkat", Bisnis.com, https://surabaya.bisnis.com/ read/20181210/444/867764/aduan-masyarakat-kasus-fintech-lending-membengkak (diakses 08 Agustus 2019).

50 Wisnu Nugroho, "Menangkap Makna Restrukturisasi dan Pemecatan Karyawan di Bukalapak", Info Komputer https://infokomputer.grid.id/read/121849751/menangkap-makna-restukturisasi-dan-pemecatan-karyawandi-bukalapak (diakses 04 April 2020). 
Atas arahan dari Presiden, dua Naskah Akademik tersebut kemudian diselaraskan dan diharmonisasi dalam pembahasan antara Dewan Perwakilan Rakyat dan Pemerintah pada 25 Maret 2008 dan kemudian ditetapkan menjadi undang-undang oleh Presiden pada 21 April 2008 dalam Undang-Undang Nomor 11 Tahun 2008 tentang Informasi dan Transaksi Elektronik yang menjadi tonggak munculnya rezim Hukum Siber di Indonesia. ${ }^{51}$

Namun seperti yang telah dijelaskan pada pembahasan sebelumnya, bahwa lahirnya Undang-Undang Informasi dan Transaksi Elektronik seolah menekan eksistensi undangundang yang berkaitan dengan Teknologi Informasi dan Transaksi. Salah satu contohnya adalah redupnya Undang-Undang Nomor 36 Tahun 1999 tentang Telekomunikasi. Undang-undang tersebut selama beberapa saat sempat menjadi rumusan norma yang mengatur tentang Teknologi Informasi dan Komunikasi. ${ }^{52}$

Konstruksi pengaturan Hukum Siber yang dibawa oleh Hukum Telekomunikasi, Hukum Media dan Hukum Informatika (Telematika) yang terdapat dalam peraturan perundangundangan sebelum Undang-Undang Informasi dan Transaksi Elektronik berakar pada konsep konvergensi Hukum dengan Teknologi Informasi yang melahirkan beberapa istilah seperti Hukum Teknologi Informasi (Law of Information Technology), Hukum Dunia Maya (Virtual World Law), dan Hukum Mayantara. Secara harfiah, istilah tersebut lahir dari hasil kegiatan yang dilakukan melalui jaringan sistem komputer dan sistem komunikasi. Penjelasan tersebut secara eksplisit termaktub di dalam penjelasan atas UndangUndang Informasi dan Transaksi Elektronik. ${ }^{53}$ Konvergensi Hukum yang merupakan marwah dari rezim Hukum Siber merupakan pondasi yang penting dalam upaya rekonstruksi Hukum Teknologi Informasi dan Komunikasi. Menurut Heidegger, pendekatan hukum konvergensi merupakan pendekatan yang menitikberatkan pengaruh teknologi dalam perkembangan hukum. Karakteristik dari teknologi itu sendiri perlu dikonstruksikan dalam hukum formal yang ideal sehingga teknologi yang berperan sebagai alat dapat dimaksimalkan fungsinya untuk mengatur masyarakat secara lebih efektif dan efisien sehingga dapat menstimulasi kemanfaatan. ${ }^{54}$

Selain permasalahan-permasalahan berkaitan dengan penyelenggaraan Hukum tentang Teknologi Informasi dan Komunikasi yang telah di paparkan pada pembahasan sebelumnya, momentum wacana akan Omnibus Law yang berhembus beberapa waktu ini juga menjadi momentum yang tepat untuk mengkodifikasi ulang peraturan perundangundangan yang mengatur tentang Teknologi Informasi dan Komunikasi yang saat ini terdiaspora. Menurut Prof.Mahfud MD, secara teknis yuridis tidak terdapat permasalahan berkaitan dengan penerapan Omnibus Law karena pada dasarnya Omnibus Law juga akan melahirkan peraturan perundang-undangan baru yang akan merevisi beberapa peraturan

\footnotetext{
51 Ahmad M. Ramli, dkk., Menuju Kepastian Hukum di Bidang: Informasi dan Transaksi Elektronik, (Jakarta: Departemen Komunikasi dan Informatika RI, 2005), hlm.32.

52 Edmon Makarim, Kompilasi Hukum Telematika, (Jakarta: Penerbit PT RajaGrafindo Persada, 2003), hlm.103.

53 Rocky Marbun, Kiat Jitu Menyelesaikan Kasus Hukum, (Jakarta: Penerbit Visimedia, 2011), hlm.121.

54 Danrivanto Budhijanto, Teori Hukum Konvergensi, (Bandung: Penerbit PT Refika Aditama, 2014), hlm.48.
} 
perundang-undangan sekaligus. ${ }^{55}$ Omnibus Law dapat efektif merevisi beberapa Hukum Teknologi Informasi dan Komunikasi.

Adapun berkaitan dengan substansi revisi yang akan menjadi materi muatan dari Omnibus Law tentang Hukum Teknologi Informasi dan Komunikasi adalah fusi dari beberapa peraturan perundang-undangan yang mengatur tentang Teknologi Informasi dan Komunikasi. Kedepannya diharapkan dapat tercipta hukum yang terintegrasi dalam satu undang-undang payung yang mengatur tentang Teknologi Informasi dan Komunikasi yang akan mengakomodasi seluruh aspek konvergensi hukum dan Teknologi Informasi dan Komunikasi, terutama unifikasi hukum antara Undang-Undang Telematika dan Undang-Undang Informasi dan Transaksi Elektronik menjadi satu yaitu Undang-Undang Teknologi Informasi dan Komunikasi.

Penulis memberikan rekomendasi komprehensif mengenai beberapa aspek vital yang memerlukan pembaharuan hukum sebagai materi muatan dari Omnibus Law Teknologi Informasi dan Komunikasi, antara lain: Pertama, Penyebaran Berita Bohong (Hoaks). Hoaks atau fenomena menyebarkan berita bohong yang meresahkan dan hingga kini menjadi problematika yang sulit diberantas. Hoaks berarti berita yang tidak benar dan tidak bersumber, dan tidak memiliki landasan faktual dan tanpa bukti yang jelas.
Namun kepercayaan masyarakat akan Hoaks juga tinggi karena Hoaks seringkali disajikan seolah-olah merupakan suatu rangkaian fakta yang dapat dipercaya, padahal Hoaks seperti berita palsu (Fake News) seringkali dibuat untuk menyesatkan orang dan untuk mendukung suatu agenda politik tertentu. ${ }^{56}$ Dalam konstruksi hukum positif Indonesia, pengaturan mengenai Hoaks melalui Teknologi Informasi dan Komunikasi tersebar di beberapa peraturan perundangundangan yang mana untuk menanganinya memerlukan interpretasi sistematis dari beberapa peraturan perundang-undangan itu. ${ }^{57}$ Momentum Omnibus Law dapat menjadi waktu yang tepat untuk merekonstruksi aspek hukum Kejahatan Mayantara berupa tindak pidana Hoaks sehingga dapat menciptakan kondisi kepastian hukum dan meminimalisir pengaruh politik dalam penegakan hukumnya sehingga hukum dapat berjalan dengan lebih objektif.

Kedua, Nama Domain Indonesia (.id). Usia dari Nama Domain Indonesia sendiri sejak diluncurkan pertama kali ke publik masih dikatakan belum lama. Nama Domain Indonesia yang berekstensi .id mencapai fase General Availability atau dapat diregistrasi secara luas oleh masyarakat baru pada tanggal 17 Agustus 2014 sehingga usianya belum genap mencapai 10 tahun. ${ }^{58}$ Begitu pula dengan konstruksi yuridis yang mengatur tentang Nama Domain

55 Dani Prabowo, "Begini Mekanisme Omnibus Law Gantikan Undang-Undang Lama," Kompas, https://nasional. kompas.com/read/2020/01/31/11511821/begini-mekanisme-omnibus-law-gantikan-undang-undanglama?page=all (diakses 13 Februari 2020).

56 Khoiruddin Manahan Siregar, "Integrasi Politik Hukum terhadap Tindak Pidana Pemberitaan Palsu (Hoax) di Indonesia," Jurnal Fitrah, Vol.4, No.2 (Desember 2018): 228-229.

57 Tansah Rahmatullah, "Hoax dalam Perspektif Hukum Indonesia," Jurnal Hukum Media Justitia Nusantara, Vol.8, No.2 (September 2018): 110-111.

58 detikInet, "Domain Apapun.id "Merdeka"!," Detik, https://inet.detik.com/cyberlife/d-2664288/domainapapunid-merdeka (diakses 13 Februari 2020). 
Indonesia jauh dari kondisi matang. PANDI selaku registri pengelola Nama Domain Indonesia yang berwenang meregulasi aspek pengelolaan Nama Domain Indonesia juga mengakui bahwa banyak sisi hukum Nama Domain Indonesia yang perlu dibenahi agar di kemudian hari tidak muncul problematika kontekstual dikarenakan celah yuridis dalam pengaturan Nama Domain Indonesia yang ada saat ini. ${ }^{59}$ Aspek keperdataan akan Nama Domain Indonesia merupakan aspek hukum yang belum disentuh secara komprehensif oleh pemangku kepentingan. Menurut penulis, Nama Domain Indonesia harus dilekatkan dengan Hak Milik sebagai hak kebendaan yang tepat serta menggunakan Perjanjian Beli-Sewa dalam konstruksi perdata karena mengingat prosedur registrasi dari Nama Domain Indonesia yang unik. Secara teknis, Nama Domain Indonesia yang terdiri dari Nama Domain dan Alamat IP (Internet Protocol) menurut penulis merupakan benda bergerak tak berwujud, namun diasosiasikan dengan benda tidak bergerak karena Nama Domain memerlukan Server Computer untuk menyimpan data Nama Domain yang bersifat virtual dan digital. Sehingga perikatan yang harus dituntaskan terlebih dahulu adalah pembelian Hak Milik atas Nama Domain Indonesia. Kemudian dilanjutkan dengan perikatan sewa menyewa Server Computer untuk menyimpan data Nama Domain karena Nama Domain tidak mungkin dapat berfungsi tanpa peran dari Server Computer. Aspek perdata ini perlu dipenetrasi dalam Omnibus Law Teknologi Informasi dan Komunikasi.

Ketiga, Model Bisnis Start-Up (Perusahaan Rintisan). Start-Up atau secara harfiah diartikan sebagai Perusahaan Rintisan adalah model bisnis yang berkembang dalam momentum digitalisasi yang dinamakan Revolusi Industri 4.0. Start-Up pada umumnya merupakan model bisnis yang tidak dapat secara parsial dikaji tanpa pengaruh dari Teknologi Informasi dan Komunikasi. StartUp pada dasarnya merupakan perusahaan yang didesain untuk tumbuh dengan waktu yang relatif singkat, yang membawa inovasi produk baru yang bersifat disruptif terhadap kompetitor petahana di suatu pasar tertentu. Inovasi produk tersebut pada umumnya merupakan hasil dari Teknologi Informasi dan Komunikasi yang memudahkan hidup manusia. ${ }^{60}$ Terdapat setidaknya lima faktor yang dapat menentukan arah keberhasilan suatu perusahaan dengan model Start-Up, yaitu Business Model , Idea, Timing, Team, dan Funding. ${ }^{61}$ Adapun yang perlu menjadi anotasi adalah peraturan perundang-undangan yang ada saat ini belum secara komprehensif mengatur mengenai aspek hukum atas StartUp. Konstruksi hukum yang ada dari segi keperdataan belum memberikan posisi yang terang bagi perusahaan Start-Up, khususnya dari sisi hukum perusahaan yang secara teknis dapat diimplementasikan, hukum atas investasi permodalan bagi perusahaan Start-Up oleh pemilik modal asing, dari segi

\footnotetext{
59 PANDI, "Kompetisi Penulisan dan Debat Hukum Nama Domain Indonesia," PANDI, https://pandi.id/kompetisipenulisan-dan-debat-hukum-nama-domain-indonesia/ (diakses 13 Februari 2020).

60 Aspari Wahyu Kurnianti, "Komunikasi Pemasaran Transportasi Online NGuberJEK," Jurnal Komunikasi dan Kajian Media, Vol.1, No.1 (Oktober 2017): 74-75..

61 Mardi Arya Jaya, dkk., "Analisis Faktor Keberhasilan Startup Digital di Yogyakarta," Prosiding SNATIF Ke-4 (2017): 168. (ISBN : 978-602-1180-50-1)
} 
persaingan usaha yang berpotensi merugikan pelaku usaha, serta korelasi dengan Teknologi Informasi dan Komunikasi yang paling riskan adalah terkait dengan perlindungan data pribadi yang perlu ditegaskan aspek hukumnya dalam Omnibus Law tentang Hukum Teknologi Informasi dan Komunikasi mengingat StartUp sangat bergantung pada pengelolaan data pengguna. ${ }^{62}$ Sehingga hukum Start-Up perlu diintegrasikan dalam Omnibus Law Teknologi Informasi dan Komunikasi untuk menghasilkan peraturan perundang-undangan yang presisi dan holistik.

Keempat, Inovasi Keuangan Digital (Financial Technology). Financial Technology termasuk dalam produk Revolusi Industri yang bersifat disruptif berupa produk pengelolaan keuangan atau finansial yang membawa inovasi yang bersifat praktis, mudah diakses, fitur yang nyaman serta biaya yang lebih ekonomis. Financial Technology memadukan peranan teknologi dengan fitur jasa keuangan, yang mana perusahaan yang mengelola tersebut biasanya memiliki kemampuan untuk bertahan dengan efisiensi kegiatan usaha yang biaya operasionalnya lebih rendah dibanding dengan petahana sebagai kompetitor. ${ }^{63}$ Financial Technology memiliki beberapa jenis layanan diantaranya yang paling populer adalah di bidang Payment, Crowdfunding dan Peer to Peer Lending. ${ }^{64}$ Walaupun secara sosiologis Financial Technology dapat mempermudah kehidupan masyarakat, namun dari sisi yuridis belum terdapat perangkat hukum yang memadai untuk mengatur segala aspek hukum atas Financial Technology. Saat ini dalam kerangka hukum positif Indonesia ada dua regulasi vital yang mengatur secara teknis tentang Financial Technology, yaitu POJK Nomor 77/POJK.01/2016 tentang Layanan Pinjam Meminjam Uang Berbasis Teknologi Informasi dan POJK Nomor 13/POJK.02/2018 tentang Inovasi Keuangan Digital di Sektor Jasa Keuangan. Menilik pada permasalahan berupa celah hukum yang ditemukan dalam konstruksi Hukum Financial Technology sehingga menurut penulis diperlukan pembaharuan hukum untuk menciptakan kepastian hukum dan menjamin perlindungan hukum bagi para pihak yang terlibat dalam kegiatan layanan Financial Technology. Yang perlu ditekankan sebagai substansi materi muatan dalam Omnibus Law Teknologi Informasi dan Komunikasi adalah berkaitan dengan legalitas perusahaan penyelenggara Financial Technology, yang mana diharuskan terdaftar pada OJK sebelum beroperasi. Begitu pula perusahaan yang illegal harus mendapat sanksi yang tegas untuk memberi efek jera.

Kelima, Kebijakan Pemerintah terkait Pelayanan Publik. Adanya fitur Pejabat Pengelola Informasi dan Dokumentasi (PPID) seharusnya menjadi solusi efektif dalam pelayanan keterbukaan informasi

62 Judit Nagy, et al., "The Role and Impact of Industry 4.0 and the Internet of Things on the Business Strategy of the Value Chain-The Case of Hungary," Jurnal Sustainability, Vol.10, No.10 (2018): 2.

63 Posma Sariguna Johnson Kennedy, "Literature Review: Tantangan terhadap Ancaman Disruptif dari Financial Technology dan Peran Pemerintah dalam Menyikapinya," Prosiding Forum Keuangan dan Bisnis Indonesia (FKBI), Vol.6 (2017): 172-173.

64 H2 Ventures dan KPMG, 2018 Fintech100 - Leading Global Fintech Innovators, (Sydney: Penerbit H2 Ventures dan KPMG, 2018), hlm.4. 
pada masyarakat khususnya untuk aktivitas legislasi. Namun sarana dan prasarana yang kurang menunjang fitur tersebut menimbulkan banyak celah dalam aplikasinya seperti pelayanan yang tidak satu pintu yang menyebabkan inefisiensi waktu. $^{65}$ Maka ada baiknya momentum Omnibus Law terhadap Teknologi Informasi dan Komunikasi dimanfaatkan untuk mereformasi sistem tersebut dengan sarana yang lebih memadai misalnya dengan menggunakan Web Semantik guna mengoptimalkan otomatisasi layanan keterbukaan informasi publik. Penggunaan sistem tersebut perlu diamanatkan melalui Omnibus Law tentang TIK.

Keenam, Perizinan Berusaha Secara Daring. Saat ini dengan adanya fase digitalisasi menuntut pemerintah untuk membangun sistem hukum yang dapat mengakomodasi kebutuhan dan kepentingan rakyat akan izin usaha. Permasalahan berkaitan dengan kewajiban perizinan usaha terutama untuk usaha yang memanfaatkan Teknologi Informasi dan Komunikasi. Pemerintah yang telah melakukan terobosan hukum dengan mengundangkan Peraturan Pemerintah Nomor 80 Tahun 2019 tentang Perdagangan Melalui Sistem Elektronik. Melalui regulasi itu, Toko Online yang melakukan kegiatan perdagangan secara kontinu diwajibkan memiliki izin usaha untuk memberikan perlindungan hukum khususnya bagi konsumen. Tapi, permasalahan yang perlu digarisbawahi adalah kewajiban tersebut tidak disertai dengan sanksi pidana atau administratif. Melalui Omnibus Law Teknologi Informasi dan Komunikasi dapat menjadi momentum yang tepat untuk melengkapi norma tersebut.

Ketujuh, Integrasi dengan Undang-Undang Telematika. Unifikasi khususnya antara Undang-Undang Informasi dan Transaksi Elektronik dan Undang-Undang Telematika perlu diselaraskan untuk meminimalisir masalah hukum yang dapat terjadi di masa yang akan datang melalui Omnibus Law TIK.

\section{Penutup}

Teknologi Informasi dan Komunikasi secara hukum tersebar dalam beberapa peraturan perundang-undangan namun memiliki marwah yang sama yaitu konvergensi antara hukum dan teknologi. Apabila ditinjau secara yuridis, regulasi yang ada saat ini memiliki banyak problematika dan celah hukum karena regulasi tersebut dibentuk dalam sejarah dan momentum yang berbeda namun pada rezim hukum yang serupa yaitu resim Teknologi Informasi dan Komunikasi. Beberapa topik mayor yang seringkali bersentuhan dengan masyarakat ternyata dari sisi Das Sollen masih mengandung banyak isu hukum yang perlu dikaji lebih komprehensif seperti Kejahatan Mayantara, bisnis Start-Up, Nama Domain Indonesia, Inovasi Keuangan Digital, keterbukaan dan pelayanan publik, serta aspek lain yang bersinggungan dengan hukum Telematika.

Wacana implementasi konsep Omnibus Law merupakan momentum yang tepat untuk mengharmonisasi, merevisi, menyelaraskan, mengintegrasi, mereformasi, merekonstruksi dan mengunifikasi Hukum Teknologi Informasi dan Komunikasi guna menghadapi

65 Ndohbea Kenda, "Implementasi Pejabat Pengelola Informasi dan Dokumentasi (PPID) pada Pemerintah Provinsi Gorontalo," Jurnal Penelitian Komunikasi dan Opini Publik, Vol.19, No.3 (Desember 2015): 174. 
tantangan di era digital. Omnibus Law sebagai konsep yang menyatukan banyak topik yang pada awalnya parsial dalam satu benang merah normatif yang komprehensif, holistik dan akomodatif merupakan urgensi yang harus segera diterapkan untuk menyatukan kepingan peraturan perundang-undangan yang mengatur mengenai Teknologi Informasi dan Komunikasi dalam satu kali revisi hukum secara menyeluruh. Kedepannya untuk mengoptimalkan penerapan Hukum Teknologi Informasi dan Komunikasi diharapkan dibentuk suatu undang-undang payung yang mengatur terutama topik mayor yang telah dikaji diatas.

Pemerintah beserta DPR diharapkan dapat merevisi dan membentuk Omnibus Law tentang Teknologi Informasi dan Komunikasi sebagai Umbrella Act yang mengakomodasi pengaturan konvergensi antara teknologi dan hukum. Kedepannya dengan diimplementasikannya Omnibus Law tentang Teknologi Informasi dan Komunikasi diproyeksikan meminimalisir permasalahan kontekstual. Sehingga tercipta konstruksi hukum TIK yang berkepastian hukum.

\section{Daftar Pustaka}

\section{Buku}

Aditiawarman, Mac, dkk., Hoax dan Hate Speech di Dunia Maya, (Padang: Penerbit Lembaga Kajian Aset Budaya Indonesia Tonggak Tuo, 2019).

B., Sukismo, Karakter Penelitian Hukum Normatif dan Sosiologis (Yogyakarta: Penerbit PUSKUMBANGSI LEPPA UGM, tanpa tahun).

Budhijanto, Danrivanto, Teori Hukum Konvergensi (Bandung: PT Refika Aditama, 2014).

Chazawi, Adami dan Ardi Ferdian, Tindak Pidana Informasi dan Transaksi Elektronik (Malang: Penerbit Media Nusa Creative, 2015).
Dewi, Shinta, CyberLaw - Praktik Negara-Negara dalam Mengatur Privasi dalam E-Commerce (Bandung: Penerbit Widya Padjajaran, 2009).

Direktorat Akunting dan Sistem Pembayaran dan Direktorat Pengedaran Uang Bank Indonesia, Laporan Pembayaran dan Pengedaran Uang (Jakarta: BI, 2008).

Drajat, Andika dan Dika Kartika, Start-Up Guidebook, Panduan Memulai Start-Up Bisnis Yang Harus Kamu Tau (Bantul: Penerbit Quadrant, 2017).

Google dan Temasek, e-Conomy SEA 2018 Southeast Asia's Internet Economy Hits an Inflection Point (Singapura: Penerbit Google dan Temasek, 2018).

Hadisoeprapto, Hartono, Seri Hukum Perdata : Pokok-Pokok Hukum Perikatan dan Hukum Jaminan (Yogjakarta : Penerbit Liberti, 1984).

H2 Ventures dan KPMG, 2018 Fintech100 Leading Global Fintech Innovators (Sydney: Penerbit $\mathrm{H} 2$ Ventures dan KPMG).

Ibrahim, Johnny, Teori dan Metodologi Penelitian Hukum Normatif (Malang: Penerbit Bayumedia, 2007).

Kementerian Koordinator Bidang Perekonomian Republik Indonesia, Pedoman Perizinan Berusaha Melalui Sistem OSS untuk Pelaku Usaha (Jakarta: Kementerian Koordinator Bidang Perekonomian Republik Indonesia, 2018).

Makarim, Edmon, Kompilasi Hukum Telematika (Jakarta: RajaGrafindo Persada, 2003).

Marbun, Rocky, Kiat Jitu Menyelesaikan Kasus Hukum (Jakarta: Visimedia, 2011).

Marzuki, Peter Mahmud. Penelitian Hukum, (Jakarta : Penerbit Kencana, 2007).

Maskun, Kejahatan Siber - Cybercrime, (Jakarta: Penerbit Kencana, 2013).

Ramli, Ahmad M. dkk., Menuju Kepastian Hukum di Bidang: Informasi dan Transaksi Elektronik (Jakarta: Departemen Komunikasi dan Informatika RI, 2005).

Rosadi, Sinta Dewi, Cyber Law - Aspek Data Privasi Menurut Hukum Internasional, Regional dan Nasional (Bandung: Penerbit PT Refika Aditama, 2015).

Santoso, Djohari dan Acmad Ali, Hukum Perjanjian Indonesia (Yogyakarta: Penerbit Perpustakaan Fakultas Hukum Universitas Islam Indonesia, 1989).

Soemitro, Roni H., Metodologi Penelitian Hukum dan Jurimetri (Jakarta: Ghalia, 1988). 
Subekti, Aneka Perjanjian (Bandung: Penerbit PT Citra Aditya Bakti, 1989).

Suparni, Niniek, Cyberspace dan Antisipasi Pengaturannya (Jakarta: Sinar Grafika, 2009).

Supriyadi, Daniar, Hukum dan Sistem Informasi Legislasi (Malang: Nuswantara, 2017).

Suseno, Sigid, Yurisdiksi Tindak Pidana Siber (Bandung: PT Refika Aditama, 2012).

Wijayanto, Doni, Legal Start-Up Business (Solo: Penerbit Metagraf, 2018)

Wijaya, Andika, Aspek Hukum Bisnis Transportasi Jalan Online (Jakarta: Penerbit Sinar Grafika, 2016).

\section{Makalah/Artikel/Prosiding/Hasil Penelitian}

Febriantoro, Wicaksono, "Kajian dan Strategi Pendukung Perkembangan E-Commerce Bagi UMKM di Indonesia," Jurnal Manajerial, Vol.3, No.5 (Juni 2018).

Harahap, Berry A. dkk., Perkembangan Financial Technology terkait CBCD terhadap Transmisi Kebijakan Moneter dan Makroekonomi, (Jakarta : BI, 2017).

Hestin Mulyasari, Thanh Thi Bi Dan, dan A. Bima Murti Wijaya, "Analisis Jenis Sistem Pembayaran Elektronik dalam Transaksi E-Commerce di Indonesia" (makalah disampaikan pada SENTIKA, Yogyakarta, 15 Mei 2014). (ISSN : 2089-9813).

Hotimah, Husnul, Hoax dalam Perspektif UndangUndang Nomor 19 Tahun 2016 tentang Informasi dan Transaksi Elektronik dan Hukum Islam, Skripsi, (Tangerang: UIN Syarif Hidayatullah Jakarta, 2018).

Industry 4.0 and the Internet of Things on the Business Strategy of the Value Chain-The Case of Hungary," Jurnal Sustainability, Vol.10, No.10 (2018).

Isra, Saldi, "Peran Mahkamah Konstitusi dalam Penguatan Hak Asasi Manusia di Indonesia," Jurnal Konstitusi, Vol.11, No.3 (September 2014).

Jaya, Mardi Arya, dkk., "Analisis Faktor Keberhasilan Startup Digital di Yogyakarta," Prosiding SNATIF Ke-4 (2017). (ISBN : 978-6021180-50-1)

Kenda, Ndohbea, "Implementasi Pejabat Pengelola Informasi dan Dokumentasi (PPID) pada Pemerintah Provinsi Gorontalo," Jurnal Penelitian Komunikasi dan Opini Publik, Vol.19, No.3 (Desember 2015).
Kennedy, Posma Sariguna Johnson, "Literature Review: Tantangan terhadap Ancaman Disruptif dari Financial Technology dan Peran Pemerintah dalam Menyikapinya," Prosiding Forum Keuangan dan Bisnis Indonesia (FKBI), Vol.6 (2017).

Kurnianti, Aspari Wahyu, "Komunikasi Pemasaran Transportasi Online NGuberJEK," Jurnal Komunikasi dan Kajian Media, Vol.1, No.1 (Oktober 2017).

Mardani, Akh., Konsekuensi-Konsekuensi Modernitas: Perubahan Perilaku Konsumen dan Kontestasi Tanda di Dunia Maya, Tesis, (Surabaya: Unair, 2017).

Nagy, Judit, et al., "The Role and Impact of Nofie Iman, "Financial Technology dan Lembaga Keuangan", (makalah disampaikan pada Gathering Mitra Linkage BSM, Yogyakarta, 22 November 2016).

Passagi, Jonathan Hendson dan Reski Amalia, "Mengenal Financial Technology di Indonesia," CTRL+ Bulletin, Penerbit Center for Law, Technology, RegTech and LegalTech Studies, Yogyakarta, Artikel 1, (2019).

Rahmatullah, Tansah, "Hoax dalam Perspektif Hukum Indonesia," Jurnal Hukum Media Justitia Nusantara, Vol.8, No.2 (September 2018).

Siregar, Khoiruddin Manahan, "Integrasi Politik Hukum terhadap Tindak Pidana Pemberitaan Palsu (Hoax) di Indonesia," Fitrah Jurnal Kajian Ilmu-IImu Keislaman, Vol.4, No.2 (Desember 2018).

Toruan, Henry Donald Lbn., "Pembentukan Regulasi Badan Usaha dengan Model Omnibus Law", Jurnal Hukum tô-râ, Vol.3, No.1 (April 2017).

Venalia, Raisa dan Ratna Januarita, "Pengawasan Otoritas Jasa Keuangan terhadap Layanan Pinjam Meminjam Berbasis Teknologi Informasi Dihubungkan dengan Prinsip Transparansi dalam Mekanisme Financial Technology di Indonesia," Prosiding IImu Hukum, Vol.5, No.1 (Februari 2019).

\section{Internet}

Aldila, Nindya, "Aduan Masyarakat : Kasus Fintech Lending Meningkat", Bisnis. com, https://surabaya.bisnis.com/ read/20181210/444/867764/aduan- 
masyarakat-kasus-fintech-lendingmembengkak (08 Agustus 2019).

Antonio, Rabbit, "Fenomena Bakar Uang Ala Startup dan Gelembung Ekonomi," Kompasiana, https://www.kompasiana.com/basingbe/5d efa080097f36616a7a4d92/fenomena-bakaruang-ala-startup-dan-gelembung-ekonomi (13 Februari 2020).

Ardani, Febri, "Babak Baru Sengketa Domain BMW.id", CNN Indonesia, https://www.cnnindonesia.com/ teknologi/20180818233634-384-323295/ babak-baru-sengketa-domain-bmwid Maret 2020).

Arif, "Bukalapak Hingga Dana, Ini StartUp yang Masih Bakar Uang," CNBC Indonesia, https://www.cnbcindonesia. com/tech/20191210151827-37-121924/ bukalapak-hingga-dana-ini-Start-Up-yangmasih-bakar-uang (13 Februari 2020).

detikInet, "Domain Apapun.id "Merdeka"!," Detik, https://inet.detik.com/cyberlife/d-2664288/ domain-apapunid-merdeka (13 Februari 2020).

Fenalosa, Aldo, "Kilas Balik Ecommerce Platform di Indonesia Tahun 2018," iPrice, https://iprice. co.id/trend/insights/kilas-balik-e-commercedi-indonesia-tahun-2018/ (2 Februari 2020).

Harris, Freddy, "Konstruksi Hukum Nama Domain: Sebuah Kepemilikan atau Lisensi", Kemenkumham, http://ditjenpp. kemenkumham.go.id/hukum-teknologi/669konstruksi-hukum-nama-domain-sebuahkepemilikan-atau-lisensi.html (23 Maret 2020).

Lubis, M.Syahran W.,"OJK Terbitkan Aturan Fintech, Ini Poin-Poinnya", Bisnis, https://finansial. bisnis.com/read/20180902/89/834081/ojkterbitkan-aturan-fintech-ini-poin-poinnya (13 Februari 2020).

Nugroho, Wisnu, "Menangkap Makna Restrukturisasi dan Pemecatan Karyawan di Bukalapak", Info Komputer https:// infokomputer.grid.id/read/121849751/ menangkap-makna-restukturisasi-danpemecatan-karyawan-di-bukalapak (04 April 2020).
PANDI, "Kompetisi Penulisan dan Debat Hukum Nama Domain Indonesia," PANDI, https:// pandi.id/kompetisi-penulisan-dan-debathukum-nama-domain-indonesia/ (13 Februari 2020).

PANDI, "Perpanjang Domain," PANDI, https:// pandi.id/mengelola-domain/perpanjangdomain/ (13 Februari 2020).

PANDI, "Statistik PANDI," PANDI, https://pandi.id/ statistik/ (diakses 13 Februari 2020).

Prabowo, Dani, "Begini Mekanisme Omnibus Law Gantikan Undang-Undang Lama," Kompas, https://nasional.kompas.com/ read/2020/01/31/11511821/beginimekanisme-omnibus-law-gantikan-undangundang-lama (13 Februari 2020).

Putra, Nanda Narendra, "Fintech Rawan Dipakai untuk Pencucian Uang dan Pendanaan Terorisme," Hukum Online, http:// www.hukumonline.com/berita/baca/ It5946e0e4c4d4c/fintech-rawan-dipakaiuntuk-pencucian-uang-dan-pendanaanterorisme (13 Februari 2020).

Prabowo, Haris, "Banjir Kasus Pasal Karet UU ITE Sepanjang 2019", Tirto.id, https://tirto.id/ banjir-kasus-pasal-karet-uu-ite-sepanjang2019-eo4V (04 Maret 2020).

Ramli, Ahmad M., "Dinamika Konvergensi Hukum Telematika dalam Sistem Hukum Nasional," Kemenkumham, http://ditjenpp. kemenkumham.go.id/hukum-teknologi/668dinamika-konvergensi-hukum-telematikadalam-sistem-hukum-nasional.html (diakses 13 Februari 2020).

Saraswati, Puspita, "AFPI Dalami Kasus Pelanggaran Standar Penagihan FINTECH", Kontan, https:// keuangan.kontan.co.id/news/afpi-dalamikasus-pelanggaran-standar-penagihan-fintech (diakses 07 Agustus 2019).

Syaidri, Muhammad, "Berkas Lengkap, Penyebar Isu Rush Money Segera Disidang", JawaPos, https://www.jawapos.com/nasional/hukumkriminal/25/01/2017/berkas-lengkappenyebar-isu-rush-money-segera-disidang/ (diakses 04 April 2020). 